\title{
The dilemma of NGOs and participatory conservation
}

\author{
Gani Aldashev ${ }^{\mathrm{a}}$, Elena Vallino ${ }^{\mathrm{b}, \mathrm{c}, *}$ \\ ${ }^{a}$ ECARES, Solvay Brussels School of Economics and Management, Université Libre de Bruxelles (ULB), Belgium \\ ${ }^{\mathrm{b}}$ Department of Environment, Land and Infrastructure Engineering, Politecnico di Torino, Italy \\ ${ }^{\mathrm{c}}$ Turin Center on Emerging Economies, Collegio Carlo Alberto, Torino, Italy
}

\section{A R T I C L E I N F O}

Article history:

Available online 2 August 2019

\section{JEL codes:}

L31

019

013

Q15

Q26

Keywords:

Participatory conservation

NGOs

Local development

Land use

Agriculture

\begin{abstract}
A B S T R A C T
Participatory conservation projects imply direct involvement of local communities in natural conservation efforts, aiming at combining economic development with protecting the environment. NGOs engaged in both development and conservation massively implement such projects. Numerous field studies document mixed results of such interventions and the persistence of conservationdevelopment tradeoff: better conservation comes at the expense of lowering the livelihoods of community members because they have to abstain from using the conservation area for hunting or agriculture. Economists argue that transferring property rights to relevant stakeholders would provide the right incentives for escaping this tradeoff. We build a simple model explaining why this policy might be insufficient. If the revenue from the conservation project is low and/or volatile, the community members may rationally reject conservation unless the NGO allocates a part of resources to sustaining community livelihoods (e.g. by agricultural extension). Hence, the NGO should deviate from its narrow mission to reach its broader objective. If the NGO is funded by strictly environmentally-oriented donors it may struggle to justify diverting a part of resources to agricultural extension, as such donors obtain little "warm-glow" utility from giving to the NGO that substantially engages in non-core mission activities. Thus, the NGO faces a "size versus efficiency" dilemma: poorly conserving a larger area (with non-cooperating local communities but happier donors) or conserving well a smaller area (with cooperation by local communities but keeping donors unsatisfied).
\end{abstract}

(c) 2019 Elsevier Ltd. All rights reserved.

\section{Introduction}

In the past decades two large trends emerged in the development narrative. The first is that participation of target beneficiaries in project design and implementation is necessary for project success (Mansuri \& Rao, 2004). In the implementation phases projects managers apply a wide spectrum of participation concepts, ranging from mere community consultation to effective involvement in decision-making (Bixler, Dell'Angelo, Mfune, \& Roba, 2015). However, the shared final aim of this approach is to increase beneficiaries' incentives and motivations to behave in ways that lead to improvement of project outcomes. The second is that the objective of environmental conservation can, and should, be coupled with economic development (Garnett, Sayer, \& Du Toit, 2007). Scholars

\footnotetext{
* Corresponding author at: Department of Environment, Land and Infrastructure Engineering, Politecnico di Torino, Corso Duca degli Abruzzi 24, 10129 Torino, Italy. E-mail addresses: gani.aldashev@ulb.ac.be (G. Aldashev), elena.vallino@polito.it (E. Vallino).
}

and practitioners provide different arguments: first a moral one, according to which poverty alleviation should be prioritized even if conservation needs are in place. Second, a utilitaristic one: strict "no-resource-use" and "fines and fences" policies with respect to protected areas in the long run harm conservation because it creates hostility from the poor local community and strong incentives for rules violation. Nevertheless, improvements in local income are supposed to increase community commitment to conservation (Adams \& Hutton, 2007). Additionally, in many contexts, participation is considered one of the most effective channels to solve the development-conservation trade-off (Bixler et al., 2015). As a consequence, one observes a massive spread of the so-called "participatory conservation" projects in developing countries, implemented by various development cooperation actors.

Participatory conservation is a major current practice in settings where a developing-country community lives in an area with a natural resource that needs to be protected. Participatory conservation directly involves the community in conservation activities, granting them with certain rights and imposing certain responsibilities linked to these activities. In turn the community is 
expected to consistently decrease the exploitation of the resources that are supposed to be conserved. Such practice is also called "integrated conservation and development projects" (ICDPs) and "community-based natural resource management" (CBNRM) (Hughes \& Flintan, 2001; Twyman, 2017), and it has been extensively studied by scholars from several disciplines (Gasteyer et al., 2016; Reid et al., 2016; Bouamrane et al., 2016; Agrawal, Hajjar, Liao, Rasmussen, \& Watkins, 2018).

This paper builds an economic model explaining why participatory conservation emerged, why it failed in various contexts, and why environmental NGOs face difficulties in making it function. To the best of our knowledge, this is the first paper that build a theoretical economic model analyzing the contradictions of participatory conservation coming from the interaction between the incentives of local communities, NGOs, and donors. When facing the tradeoff between environment conservation and local economic development, a standard response from some streams of economic theory would recommend to transfer property rights to the local community over the endangered area and this would provide them sufficient pecuniary incentives to solve the tradeoff. However, as we will explain extensively in the next sections, numerous case studies conducted by scholars of different disciplines worldwide show that this schema does not perform as intended, mainly because the income generated by the resources over which the community gained property rights is either too low or too volatile and can not act a substitute for traditional livelihood sources. We show, from the economics perspective, why such contradictions emerge and why bottlenecks placed in the relation between the environmentally oriented NGO and its myopic donors hinders a straight solution. Our explanation focuses on the interplay between the incompleteness of contracts (between the conservation-oriented NGO and the local community) and the narrow mission of the NGO. We discuss several practical implications on the field of these reflections. We hope that our analysis will interest scholars and practitioners from disciplines beyond economics, that deal with participatory conservation projects at different decisions levels.

The main mechanism of the model is as follows. The tragedy of the commons in a given natural area justifies an outside (NGO) intervention. The NGO tries to create incentives for conservation efforts from the local stakeholders; however, according to economic theory the contractual incompleteness calls for transferring property rights over the conservation area to the local community (i.e. participatory conservation). This necessity arises because the NGO is not able to fully control farmers' behavior. Therefore, farmers need a direct incentive to behave in the way that the NGO desires in order to reach project objectives. In the schema the community is expected to strongly (although not completely) decrease the activities within the protected zone and in turn they are granted with the right to receive the tourism income generated from the conservation project. However, the community members are close to the subsistence level and are thus highly risk-averse. Consequently, they give priority to agricultural income over the more volatile tourism revenue from the conservation project. We will argue that in rural areas where livelihood is close to subsistence, this holds also in case the tourism industry promises future good performance. Thus, they rationally choose to refrain from conservation unless the NGO allocates a sufficient amount of resources to sustaining agriculture (which is expected to take place outside the park). However, the NGO - being funded by donors with strictly environmental motivation - finds it hard to justify diverting a part of funds into agriculture and risks a reduction of donors funds if it follows this practice. Thus, the NGO ends up facing the "size versus efficiency" dilemma: it can either conserve poorly a relatively large area (with non-cooperating local communities but more satisfied donors) or it can conserve better a smaller area (with cooperation by local communities but reducing the welfare of donors because of funds diversion $)^{1}$.

In order to improve the model understanding, we provide here more background on participatory conservation (PC), on its analysis in the academic literature and on the gaps that we aim to fulfill. Although the large increase in the number of these PC initiatives is rather recent, such projects have a longer history in development cooperation. An early project was the Luangwa Valley Project cofunded by the Food and Agriculture Organization and the Government of Zambia in the 1960s (Child \& Dalal-Clayton, 2004). The aim of the project was to secure benefits from wildlife management for the local communities. By the 1990s, the concept of participatory conservation entered the initiatives of most major international organizations (Wells, McShane, Dublin, O'Connor, \& Redford, 2004). As noted by Garnett et al. (2007), “Organizations whose primary mission is conservation and those whose mission is development have both adopted the ICDP approach in some form". Consequently, the definition of participatory conservation has expanded, so that such projects are now described as " $(. .$. approaches to the management and conservation of natural resources in areas of significant biodiversity value that aim to reconcile the biodiversity conservation and socioeconomic development interests of multiple stakeholders at local, regional, national and international levels" (Franks \& Blomley, 2004, cited in Garnett et al., 2007: 2).

Usually participatory conservation implies creating a protected area, with the local community becoming its stakeholder (in part or completely), and being directly involved in the decisionmaking process. The community takes over various responsibilities concerning the management of the conservation area and receives the income generated from the conservation efforts, mainly through tourism. This requires, however, that the community commits to exploiting only a limited quantity of the resources of the conserved area and to pursuing the agricultural, grazing, or hunting activities strictly outside of the protected area (Hughes \& Flintan, 2001; Blaikie, 2006; Garnett et al., 2007; Galvin \& Haller, 2008; Murphree, 2002).

The proponents of participatory conservation put forward three main reasons for these projects. The first is the frequent failure in conservation of top-down approaches calling for complete community physical exclusion from State owned protected areas. Second is the recognition that the cooperation of local population (both with project managers and within the community) is key for effective conservation since it decreases motivation for rule violation (Edmonds, 2002; Ostrom, 1990). Finally, these projects guarantee access rights (to different degrees according to the specific context) to natural resources for local communities whose livelihood depends on those resources. They thus demonstrate a difference, at least in the intentions, with the traditional approach of protected areas governance, shifting to a no-resource-use concept to a sustainable-use narrative that should be compatible with both conservation and local development (Ostrom, 1990; Baland \& Platteau, 1996; Agrawal, 2007; Campbell \& Vainio-Mattila, 2003; Adams \& Hutton, 2007).

However, the success of participatory conservation in meeting either conservation or development objectives in practice has been, at best, mixed. These two large objectives are rarely integrated, as synergies do not emerge spontaneously. There are numerous cases of failure to reach the conservation objective,

\footnotetext{
${ }^{1}$ As we will explain in the dedicated section, the NGO has limited resources, therefore by definition if it spends more in agriculture it must decrease expenses for the park. For the sake of simplicity, we assume with "size" every physical or monetary output derived from investments in the park (therefore not necessarily related to a geographical size). With "efficiency" we mean the degree of commitment to conservation by the local community.
} 
and the loss of biodiversity is common. The successes in the environmental dimension are rarely linked to substantial permanent improvements in the wealth and well-being of the communities in which the interventions took place. Such successes are cherrypicked by PC proponents as anecdotal case studies; however, at closer inspection, they appear crucially depending on temporary and local contingencies (Garnett et al., 2007; Murphree, 2002).

In academic literature, participatory conservation projects are objects of critiques both from a theoretical point of view and on the basis of empirical findings (Blaikie, 2006; Herrold-Menzies, 2006; Hsing-Sheng, 2007; Galvin \& Haller, 2008; Vallino, 2009; Vallino, 2013; Gasteyer et al., 2016). Several authors argue that the trade-off between conservation and development goals is unavoidable (Barrett \& Arcese, 1995; Hsing-Sheng, 2007), especially in settings with very low-income rural areas (Bulte \& van Soest, 2001). For instance, the goals of wildlife conservation and that of income generation from wildlife-based activities are often mutually exclusive (Barrett \& Arcese, 1995; Oates, 1999; Wunder, 2001; Kideghesho, 2008; Kovács, Fabók, Kalóczkai, \& Hansen, 2016). Others highlight that the existence and the magnitude of the trade-off depends on the specificities of the local context, thus advocating against broad generalizations (Koop \& Lise, 1999; Kovács et al., 2016). In some cases, conservation and economic development might be complementary and the dynamics of the interaction between the advancements in the two dimensions is highly context-specific (Van Laerhoven \& Ostrom, 2007; Berkes, 2007; Garnett et al., 2007; Platteau, 2008).

Often, the de facto prevailing approach is still the top-down one, with the role of indigenous communities and their knowledge remaining neglected (Fairhead \& Leach, 1996; Gibson, 1999; Blaikie, 2006; Zougouri, 2006; Reid et al., 2016). In part, this is justified by the fact that the local decision-making institutions are fragile (Balint, 2006). In addition, the attempts to building sustainable income-generation alternatives based uniquely on nature or wildlife rely excessively on earnings from tourism activities, which are often highly volatile (Brown, 1998).

Finally, the political-economy dimension of the problem is also key, as conflicts between users and stakeholders frequently emerge at different levels. For instance, local users of a forest may favor resource extraction to satisfy their livelihood needs, whereas the international stakeholders may push for forest conservation for carbon storage (Dolsak \& Ostrom, 2003). Given their poverty, indigenous groups in developing countries feel crucially in need of rapid economic improvements of their conditions from conservation and tourism activities (Dhakal, Bigsby, \& Cullen, 2012). On the other hand, conservation-oriented NGOs are primarily interested in diminishing the level of resource extraction within the conservation zone, giving less weight to the economic considerations of the local community (Coria \& Calfucura, 2012; Reid et al., 2016). Auer (2006: 217) states that "these and other potentially confounding problems pose challenges for even the bestmanaged common pool resources, and some of these factors may be beyond the control of local users, rule-makers, and ruleenforcers".

We contribute to the participatory conservation literature in the following ways.

First, we translate into economic modelling what has been highlighted in field studies, in order to reply to the economic arguments according to which, as explained above, if stakeholders are provided with property rights over a resource, automatically the correct incentives emerge and they will behave in the desired way. ICDPs reality challenges this simple theoretical solution. By remaining into the field of economic modelling, we show how it is possible that this schema (transfer of property rights) still produces inefficient outcomes.
Second, we introduce directly the NGO perspective, by keeping into the same model the three dimensions: the needs and incentives of local community, of the NGO and of the donors. Moreover, we tackle interactions in two directions: between the NGO and the farmers and between the NGO and the donors. In this way we depict the NGO as an actor that has not a full freedom of decision on its relation with beneficiaries, while in turn it is subject to constraints, and it is trapped between two sources of pressure. Looking the dynamic from a "principal agent theory" perspective, we could say that the NGO is at the same time the principal (with respect to the farmer) and the agent (with respect to the donor). Third, we inform our work through, and hope to contribute to, different streams of literature: protected area governance, participatory narratives in conservation projects, integration of conservation and development, NGO behaviors.

Our work aims to fulfill a number of gaps in the related literature. In the field on participatory conservation many studies focus on intra-community dynamics (Platteau, 2004; Platteau \& Abraham, 2002; Platteau \& Gaspart, 2003; Tarui, 2007; AlixGarcia, 2008; Platteau \& Seki, 2007) or between communities (Winkler, 2011). Other studies (Barrett \& Arcese, 1998; Johannesen \& Skonhoft, 2005a, 2005b; Schulz \& Skonhoft, 1996; Skonhoft \& Solstad, 1998; Skonhoft, 1998a, 1998b), among others, concentrate on the competition in wildlife harvest between locals and a reserve management. We focus instead on the dynamics between the community and an actor like an NGO that involves the community in a program having wider scope than simply tourism management.

Some scholars problematize the PC scheme by focusing on the complexities and contradictions of practices that foster local participation into natural resource management, by critically analyzing the gaps between intentions and real power allocation for decisions (Bixler et al., 2015; Nuesiri, 2017). However, they pose relatively less attention to the trade-off between livelihood and resource conservation in itself. Some other scholars (Schulz \& Skonhoft, 1996; Fischer, Muchapondwa, \& Sterner, 2011) focus on the possible different scenarios regarding resource use versus resource preservation, by analyzing as well the dynamics of resource availability, but they lack considerations on the actual degree of community involvement in the decision making over those scenarios, although in ICDPs declarations local participation is always present. We aim to link the two discourses, by explaining which are the rational reasons from the point of view of the NGO to "grant" participation and by showing why this is not sufficient to create automatically the conditions for a behavioural change of the local farmers and to increase their commitment to conservation at the level desired by the project.

Moreover, a wide range of studies, across different disciplines, either argue that ICDP projects fail, by observing empirical results (Wells et al., 2004; Garnett et al., 2007) or that are likely to fail, by considering inherent theoretical contradictions (Barrett \& Arcese, 1995; Wells \& Bradon, 1992; Ferraro, 2001). However, to the best of our knowledge, no study explores the reasons that impede a consequent quick attitude change by the project designers, as reaction to the persistence of failures or suboptimal outcomes.

Regarding studies on environmental NGOs, Brockington, Scholfield, and Ladle (2018) analyze in depth the features of the conservation NGO sector: major players, strategies and narrative, so as relations of NGOs among them at an horizontal level. However, they do not address systematically vertical relations with the projects beneficiaries on the one hand, and, on the other hand, with donors. Distinct features of conservation NGOs, their proliferation and influence on national priorities in developing countries are documented through many case studies (among others Duffy, 2006; Lees, 2007; Larsen \& Brockington, 2018), although there is not a comprehensive discourse that connects these analyses to 
debates on protected area management and the trade-off between conservation and development at the same time.

\section{Participatory conservation in Burkina Faso and Vietnam}

An important conservation project (documented in Vallino, 2009) conducted in Western Africa presents interesting dynamics. The GEPRENAF project involved a large forest (300,000 ha) and its inhabitants in the Comoé region, located in the south of Burkina Faso and the north of Ivory Coast. The project began in 1996 and ended in 2002. The total budget for the Burkinabè part has been very large, 6.6 million US \$ (ibid.). The area involved is one of the richest of Burkina Faso from the natural point of view.

The surface devoted to agriculture is $9 \%$ of the total area under the project, but it increased dramatically from 1956 to 1998 due to immigration from other areas (ibid.). The zone attracted farmers because of high soil fertility, and because it represented a pacific area for escaping from the conflict in Ivory Coast, just across the border. The main threats to the ecosystem are the excessive extraction of forest resources by the increasing population of the surrounding villages: hunting, agriculture, animal husbandry, and bush fires for crop rotation (GEPRENAF, 1997).

The population of the beneficiary villages in the area use extensive agricultural techniques, therefore the cultivation of cash crops like cotton and yam reduces the land available for food crops, and impoverishes the soil significantly. Subsistence hunting is still largely practiced and is considered important in the local culture. Villages are highly dependent on natural resources: hunting, fishing and harvesting of forest products are additional sources of income, besides agriculture and grazing.

The GEPRENAF project, implemented in this remote isolated community, brought a large amount of financial resources and promoted the achievement of ambitious goals, although most of these goals were not properly understood by the indigenous rural population. To pursue these objectives, the GEPRENAF project first conducted a consultation and negotiation with the local community concerning the old boundaries of the pre-existing forest estate and the change of status to partially protected area. Within the protected area, the local population is allowed to harvest dry wood, fruits, medicinal plants, honey, while hunting and agriculture are prohibited inside the conservation area (but are allowed in the buffer zone). The project also foresaw the organization of tourism activities in the reserve. Secondly, the project supported the creation of the Inter-Village Association for the Management of Natural Resources and Wildlife (AGEREF), which became the concessionaire of the reserve. Thirdly, the project supported the construction of certain infrastructures in the villages, such as schools, health centers, water wells, and four buildings for hosting tourists. Finally, the project staff implemented micro-projects for income generation for the local population.

The AGEREF is responsible for the management of the different project branches: (i) reserve management (for example, local community members were hired for maintenance and anti-poaching activities); (ii) support of micro-projects and income generating activities, such as agroforestry, bee-keeping, soap production, karitè butter production, and marketing of forest products. (iii) development of safari hunting and tourism in the park; (iv) redistribution of project benefits to the local community; and (v) representing local communities in national and international institutions.

The overall assessment of the economic impact of the GEPRENAF project on the population and the level of income generated by the management of the reserve shows a weak outcome. The project improved the living conditions of the beneficiary villages through the creation of infrastructures and empowered the local communities institutionally, but in return required the confiscation of agricultural land and the enforcement of strict limitations on hunting, grazing and fishing rights within the protected area. The project did not create concrete alternatives to extensive agriculture and grazing to fulfil subsistence needs of the local people. For these reasons the whole institutional scheme is still weak and needs to be continuously legitimated. Moreover, illegal hunting and crop cultivation continue to take place inside the reserve. The reliance on safari hunting as principal source of income is not sustainable.

A key aspect where community preferences are in clear contradiction with the project designers is the construction of infrastructure. Building infrastructure, especially schools, bridges, and water wells, would have a highly positive impact on the community. However, the situation is still far from satisfying its needs. Some villages complain about lack of drinkable water. The maintenance of some infrastructure such as mills and health centers is problematic. The situation of the roads is crucial, since the project did not invest in the improvement of communication and transportation, which is essential for the achievement of the project's objectives. In a project assessment document, the World Bank affirmed that it is not possible to build a bridge over the river Comoè, which separates two clusters of villages, because it would disturb wildlife, hence going against the priorities of the project (Banque Mondiale, 2000, p. 20). Such statements demonstrate that despite the emphasis given by the project to the coupling of socioeconomic and environmental goals, in the moment of practical application, the actual authorities' priorities emerged, with a bias toward the achievement of conservation objectives.

Another case study that highlights key tensions between the project mission and the priorities of the local community is discussed by Larsen (2008).

The Phong Nha Kẻ Bàng area (PNKB) in Vietnam was established in the post-colonial time (Larsen, 2008). Since the 1930s the national Forest Code aimed at controlling and eliminating shifting cultivation within the boundaries of the so called "intact forest" area. Phong Nha was declared a small reserve (5000 ha) in 1986, and the area under protection was gradually extended during the 1990s and the 2000s up to almost 90,000 ha. In 2001 the site reached the status of National Park and in 2003 it was awarded the World Heritage Status. At the time of the study (Larsen 2008), the area under protection was in further expansion due to World Conservation Union recommendations and to the requests of an upcoming 15-million-dollar project supported by the German Financial Cooperation (KfW) and the German Agency for Technical Development (GTZ). The park is separated into three zones: a strictly protected "core" zone (64,894 ha), an ecological recovery zone (17,449 ha) and a service/administrative unit (3411 ha). In the latter living and working facilities are present, however the former two include the majority of local settlements.

Generally, in Vietnam protected area design is mostly a topdown process involving mainly central-level and provincial institutions, as well as scientific and conservation communities. In addition, in Vietnam conservation NGOs have been very active within the last decades, often playing crucial roles in the formulation of conservation strategies. General policy has traditionally had a strong "no-use" orientation. In the core protection zone, regulations forbid any forest use and human presence, although it has been estimated that up to $80 \%$ of Vietnam's protected areas are inhabited (Larsen, 2008, p. 444). The 2004 Law on Forest Protection and Development states that households can remain in the ecological restoration zone only under specific contracts for protection and development. In the PNKB area, agricultural land remains scarce. Local communities are traditionally highly forest-use 
dependent: forest use ranges from collecting firewood and nontimber products to hunting for subsistence and for national and international markets.

The PNKB protected area is officially under the responsibility of the Provincial People's Committee of Quảng Bìn. In official declarations, community participation is pursued through the "forest protection contract system", and with "awareness-raising" activities, which are considered as the main avenue to create social incentives for protected area compliance (ibid., p. 451). According to this system, forest land is assigned to households and payments are provided based on protection performance. Tourist activities are organized in some areas of the National Park, involving directly a fraction of the local population in services provision and enforcement.

According to the study (ibid.), the impact of the creation of the Protected Area on livelihood has been extremely negative, especially for ethnic minorities. Communities living in the core zone had to reduce dramatically their agricultural practices and started to live on rice subsidies. The protection contract system itself has been limited in value and scope, focusing the benefits on a relatively small share of households of the area. Those households had to bear the costs of renouncing to exploit resources in the protected area, to perform extra work for direct conservation activities, to experience very limited benefits in return.

Along with the World Heritage designation in 2003 international and domestic tourism exploded, providing ground for positive narratives on employment creation linked to the park creation (ibid. p. 452). However, in reality, tourism in this area faced multiple problems. Its absorption capacity in terms of employment for tourism services and forest guards turned out to be low, generating income for only a small fraction of population. Regarding the tourism services offered (for example, the boat tours), supply soon started to exceed the actual demand. Spin-off activities remained at a small scale and concentrated in a single community. The limited employment opportunities did not create sufficient incentives for interrupting illegal exploitation of forest resources and illegal hunting. A considerable share of tourism revenue was channeled to the Provincial authorities and not to the local community. In general, basic livelihood activities remained extremely vulnerable, constrained by lack of tenure security and limited rights to practice subsistence activities, while some communities continue to be heavily dependent on rice subsidies.

Despite the persistence of high poverty rates in the PNKB area, and despite the development of the narrative on coupling participatory conservation with livelihood support, the higher-level funding institutions seem to remain concerned solely about conservation. Community involvement in park management and income-generating activities has been encouraged mostly to enhance local consensus on conservation rather than to improve local living conditions, as noted also in many other similar initiatives worldwide (Campbell \& Vainio-Mattila, 2003):

"There is a fairly distinct national-level conservation community comprised of the Forest Protection Department, governmental and semi-governmental scientific institutions, which mainly play a role at the policy, overall systems and planning levels. Various international conservation NGOs such as WWF, Fauna \& Flora International (FFI) and German zoological societies have undertaken project activities in the area, yet have only in a very limited way touched directly upon livelihood activities. (...) Development and conservation activities tend to work in parallel without much interaction" (ibid. p. 458).

Infrastructure development such as road building (for example in the context of national development plans) has been questioned and criticized by the environmental NGO community. Funding from international conservation organizations derives from simplistic assumptions, according to which supporting to a low degree the local community and providing small economic returns from conservation would create sufficient incentives for ceasing natural resources exploitation and hunting. According to Larsen's analysis of the project documents (ibid.), the new KfW project apparently focuses more on livelihood concerns, but in reality remains ambiguous about the actual priorities. On the one hand, it promises forest land allocation, improvement of tenure security and increase of benefits in the buffer zones, while on the other hand, plans an expansion of the no-use core area and classifies agriculture and road development as threats. It uses the argument of enhancing income diversification for the "poor" to justify the prohibition of shifting cultivation (ibid. p. 461). It seems to still consider the community itself as a problem external to the park rather than an integral part of its management. Considering the general approaches of international and national actors in the conservation sector in Vietnam, Larsen (ibid.) argues that the reasons for limited room for adaptive management and overcoming of such limitations lie, on the one hand, on the fact that voices of the local community do not reach the public sphere, although they are often aware of the contradictions mentioned before. On the other hand, international donors are tied to the narrow mission of strictly reaching project objectives. Therefore, when the complexity of the interplay between conservation and local development emerges, donors tend to prioritize the former over the latter (Campbell \& VainioMattila, 2003; Songorwa, 1999).

\section{The model}

\subsection{Setup}

Our model applies to situations in which an external actor implements an ICDP project in low-income rural communities, where households are dependent for subsistence objectives on natural resources that are supposed to be protected. Consider a simple model of the tragedy of the commons (Hardin, 1968) in a community consisting of two identical farmers $(J=A, B)$ and a project by an outside non-governmental organization (NGO), whose main mission is environmental conservation. The livelihood of the farmers is based on agriculture and other subsistence activities (as explained below). Let's assume that farmers are unable to build binding cooperative agreements (otherwise, the economic problem would be assumed away); thus, in the absence of an outside intervention, a sub-optimal (excessive) use of the natural resource would occur. For simplicity, we abstract away from the internal dynamics of the farmers' community and restrict the sharing of benefits of the project to a simple equal-sharing rule. ${ }^{2}$

The community is surrounded by a natural habitat (e.g. a forest inhabited by wildlife), that the NGO, driven by its environmentalconservation motivation, would like to transform into a protected zone. ${ }^{3}$ The economy consists of three sectors: agriculture, conservation (if the NGO project takes place), and other subsistence activities of the farmers, which we label as "hunting" (but that more broadly can include harvesting of fruits and plants, grazing, fishing, wood

\footnotetext{
${ }^{2}$ Clearly, there might be a considerable inequality among the community members and thus local elite capture might arise. These issues of interactions between the community members have been widely studied (see, for instance, Platteau, 2004; Platteau \& Abraham, 2002; Platteau \& Gaspart, 2003; Winkler, 2011; Tarui, 2007; Alix-Garcia, 2008; Platteau \& Seki, 2007). However, given that development practitioners (e.g., Campbell \& Vainio-Mattila, 2003) argue that studies of interaction between project beneficiaries and project designers are scarce, in this paper we focus on this specific dimension of the problem, keeping aside the distributional issues.

3 For a good review of the literature on interventions of this kind, see Winkler (2011). Good contributions are Gordon (1954), Skonhoft (1998a, 1998b, 2007), Smith (2002), Johannesen \& Skonhoft (2005a, 2005b), and Fischer et al. (2011).
} 
collection, and other activities that provide revenue to community members but that might harm conservation). We assume from the beginning that agriculture take place outside the protected zone and what we label as "hunting" inside; therefore the second activity is the most harmful for the natural area. Each farmer is endowed with one unit of time. The farmer allocates his time budget between agriculture and hunting, so as to diversify income risks (see, e.g., Lambin \& Meyfroidt, 2010). We denote with $t_{a}^{J}$ and $t_{h}^{t}$ the time that farmer $J$ allocates to agriculture and hunting, respectively.

Technologies of production in agriculture and hunting are as follows. With probability $1-p_{a}$ the harvest is bad and the farmer's income from agriculture is low (normalized to zero). With probability $p_{a}$, the harvest is good, in which case the agricultural output of farmer $J$ is determined by a production function of the form $\beta_{0}\left(t_{a}^{t}\right)^{\alpha}$, where $0<\alpha \leq 1$ and $\beta_{0}$ is a parameter capturing the productivity of agriculture (in the absence of outside intervention).

For the hunting activity, a poor outcome ("bad year") occurs with probability $1-p_{h}$ (the probability distributions of outcomes in hunting and agriculture are assumed to be independent), in which case the income from hunting is zero. With probability $p_{h}$, a good outcome ("good year") occurs, and the farmer $A$ 's income from hunting equals $Q \frac{t_{h}^{A}}{t_{h}^{A}+t_{h}^{B}}$, where $Q$ denotes the carrying capacity of the environment in terms of wildlife resources (the expression for farmer $B$ is analogous). Notice that the good year's income from hunting has the form of a contest success function (Tullock, 1980; Perez-Castrillo \& Verdier, 1992), which we impose to capture the idea that the income-generating activity that harms conservation is subject to competition between farmers.

\subsection{Community in the absence of the NGO project}

We start by analyzing the setting in which the environmental NGO is absent. Farmer $A$ decides on the allocation of his time, so as to maximize his utility:

$\operatorname{Max}_{t_{a}^{A}, t_{h}^{A}} p_{a} \beta_{0}\left(t_{a}^{A}\right)^{\alpha}+p_{h} Q \frac{t_{h}^{A}}{t_{h}^{A}+t_{h}^{B}}, \quad$ subject to $t_{a}^{A}+t_{h}^{A}=1$.

The problem (1) reduces to an equivalent unconstrained optimization problem

$\operatorname{Max}_{t_{h}^{A}} p_{a} \beta_{0}\left(1-t_{h}^{A}\right)^{\alpha}+p_{h} Q \frac{t_{h}^{A}}{t_{h}^{A}+t_{h}^{B}}$.

The first-order condition of this problem is

$p_{a} \beta_{0} \alpha\left(1-t_{h}^{A}\right)^{\alpha-1}=p_{h} Q \frac{t_{h}^{B}}{\left(t_{h}^{A}+t_{h}^{B}\right)^{2}}$.

The left-hand side (farmer $A$ 's marginal cost of hunting time) is expressed in terms of opportunity costs with respect to his own agricultural activity, and increases with the productivity of agriculture $\left(\beta_{0}\right)$. The right-hand side (the marginal benefit of hunting) depends instead on the hunting effort of farmer $B$, as well as on the carrying capacity (the quantity of the natural resource available) $Q$.

Given that farmer B's problem is symmetric, we obtain the following best-response functions

$t_{h}^{A *}=f\left(\beta_{0}, t_{h}^{B}\right)$ and $t_{h}^{B *}=f\left(\beta_{0}, t_{h}^{A}\right)$

Solving the system of Eq. (4), we obtain the Nash equilibrium in hunting efforts of the two farmers, in the absence of NGO intervention.

To understand the shape of the reaction functions, let's write the net marginal benefit of hunting for farmer $A$ (denoting it with $Y^{A}$ ):

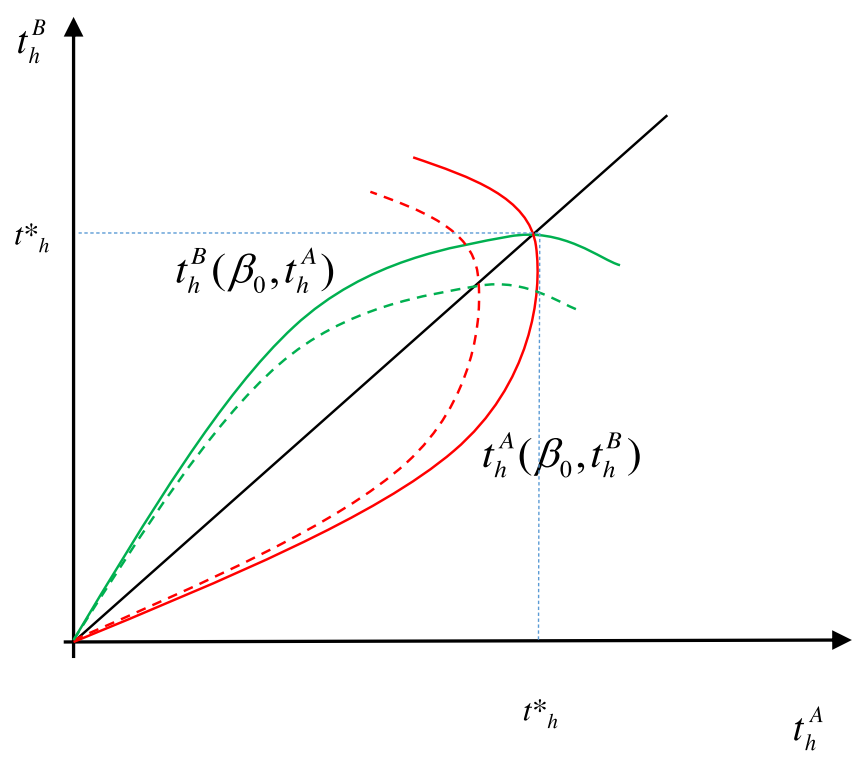

Fig. 1. Nash equilibrium hunting without NGO.

$Y^{A}=p_{h} Q \frac{t_{h}^{B}}{\left(t_{h}^{A}+t_{h}^{B}\right)^{2}}-p_{a} \beta_{0} \alpha\left(1-t_{h}^{A}\right)^{\alpha-1}=0$

Applying the implicit function theorem to the function $Y^{A}\left(t_{h}^{A}, t_{h}^{B}\right)$, we get

$$
\begin{aligned}
\frac{\partial t_{h}^{A}}{\partial t_{h}^{B}} & =-\frac{\partial Y^{A} / \partial t_{h}^{B}}{\partial Y^{A} / \partial t_{h}^{A}} \\
& =\frac{p_{h} Q\left(t_{h}^{A}-t_{h}^{B}\right)}{2 p_{h} Q t_{h}^{B}+p_{a} \beta_{0} \alpha(1-\alpha)\left(1-t_{h}^{A}\right)^{\alpha-2}\left(t_{h}^{A}+t_{h}^{B}\right)^{3}}
\end{aligned}
$$

which describes the slope of the best-response function of farmer $A$ (an analogous expression obtains for the slope of the best-response function of $B$ ). Fig. 1 presents the best-response function curves and the Nash equilibrium. Notice that given the functional form assumptions, the best-response functions are concave, the equilibrium is unique and symmetric, and, moreover, at the equilibrium, the slopes of the two curves are zero. ${ }^{4}$

The intuition is as follows. Consider farmer A's choice of time allocation. If his rival were to devote no time to hunting, the marginal benefit of hunting time for A would be very high (a tiny quantity of hunting time would give farmer $A$ the entire carrying capacity). As the rival increases his hunting time, farmer A also has the incentive to increase $t_{h}^{A}$, but at an ever decreasing rate. This occurs for two reasons: (1) the opportunity cost of hunting time (the returns from agriculture) is growing (driven by the diminishing marginal returns to time for agriculture), and (2) the marginal returns to hunting time are lower at higher values of hunting activity of the rival (by the nature of the contest success function). Beyond a certain point, the first effect outweighs the second, so that if the rival increases his hunting time even further, then farmer $A$ is better of cutting his hunting effort. The symmetry of the objective functions of the two farmers implies then that both farmers rationally expect the rival to choose the level of hunting effort exactly at the point where the two effects described above cancel each other.

\footnotetext{
${ }^{4}$ This is generally true in rent-seeking games that are modelled as contests (see Perez-Castrillo \& Verdier, 1992).
} 
The symmetry of the Nash equilibrium allows us to pin down the equilibrium symmetric value of the net marginal benefit of hunting:

$Y^{*}=p_{h} Q \frac{1}{4 t_{h}^{*}}-p_{a} \beta_{0} \alpha\left(1-t_{h}^{*}\right)^{\alpha-1}=0$.

Applying the implicit function theorem to this expression, we obtain the following simple comparative statics result:

Proposition 1. An increase in the carrying capacity of the natural area or an increase in the probability of the "good hunting year" raises the total equilibrium hunting activity. An increase in probability of the good agricultural harvest, in agricultural productivity parameter, or slowdown in the speed of diminishing marginal returns to agriculture time decreases the total equilibrium hunting:

\section{$t_{h}^{*}=t_{h}^{*}\left(p_{h}^{+}, Q^{+}, p_{a}^{-}, \beta_{0}^{-}, \alpha^{-}\right)$}

The intuition for this result is rather straightforward. Anything that increases the expected return to hunting activity, ceteris paribus, raises the marginal benefit of hunting time. Time devoted to hunting by the two farmers exhibits strategic complementarity up to the point of Nash equilibrium, i.e. when the return to hunting activity increases, the net marginal benefit from time spent hunting by farmer $A$ becomes temporarily increasing in the hunting time of farmer $B$, and vice versa. This induces both farmers to allocate more time to hunting. Similarly, anything that increases the expected return to agriculture, ceteris paribus, increases the opportunity cost of hunting. Time devoted to hunting by the two farmers exhibits strategic substitutability beyond the point of Nash equilibrium, i.e. when the opportunity cost of hunting increases, the net marginal benefit from time spent hunting by farmer $A$ becomes temporarily decreasing in the hunting time of farmer $B$, and vice versa. This induces both farmers to allocate less time to hunting. An increase in agricultural productivity leads to a shift of both curves toward the interior (dotted curves in Fig. 1).

\subsection{Community with NGO under complete contracts}

An outside actor interested in conservation (the NGO) assumes that farmers A and B are not able to cooperate and solve the tragedy of the commons emerged from the Nash equilibrium played in the above analysis ${ }^{5}$. Therefore it may consider an external intervention as necessary in order to modify the farmers' incentives and behavior. Consider now the setting in which an outside environmental NGO enters the community with a conservation project. The NGO has funds (collected from donations in a developed country), its mission is to maximize conservation, and its project consists of establishing a protected area and of encouraging the farmers to abstain from hunting (pursued within the boundaries of the zone that needs to be conserved).

As a benchmark, suppose that complete contracts between the NGO and farmers are feasible. We denote with $z$ the missionoriented expenditure by the NGO (e.g. creating and maintaining the protected area, investing into persuasion campaigns aimed at farmers, etc.). The NGO's objective is

$\operatorname{Max}_{e} Q-\gamma \sum t_{h}(z)$

where $\gamma$ is a parameter capturing the (irreversible) damage done to the environment by hunting. ${ }^{6}$ Since $Q$ and $\gamma$ are constant, this problem is equivalent to

\footnotetext{
${ }^{5}$ Since the NGO represents a broader interest in terms of conservation, from its perspective every hunting level different from zero is considered overuse.

${ }^{6}$ Given that we abstract from dynamic considerations, suppose that $Q$ is at its steady-state value.
}

$\operatorname{Min}_{e} \sum t_{h}(z)$

Assuming complete contracts, the NGO can perfectly observe the behavior of farmers and can enforce (at no cost) the actions agreed upon (see Laffont \& Martimort, 2002). In such an environment, the NGO proposes a payment scheme to the farmers: a lump-sum transfer $w$, paid out conditional on the level of hunting, similar to the widely-known payments for environmental services (PES; see, e.g., Engel \& Palmer, 2008). More specifically, the scheme can take the form: $w^{\text {high }}$ if $t_{h}=0$ and $w^{\text {low }}$ if $t_{h}>0$.

Regarding the values that $w$ should have such that the farmers prefer to accept the payment scheme ${ }^{7}$, we observe that if farmers reject the offer, they would play the Nash equilibrium derived above, $t_{h}^{*}$. This gives each of them their (symmetric Nash equilibrium) payoffs

$p_{a} \beta_{0}\left(1-t_{h}^{*}\right)^{\alpha}+p_{h} Q \frac{t_{h}^{*}}{\sum t_{h}^{*}}=p_{a} \beta_{0}\left(1-t_{h}^{*}\right)^{\alpha}+\frac{p_{h} Q}{2}$

If a farmer accepts the payment and thus chooses $t_{h}=0$, his payoff becomes

$p_{a} \beta_{0}+w^{\text {high }}$.

Consequently, the farmers accept the payment scheme if and only if

$w^{\text {high }} \geq \frac{p_{h} Q}{2}-p_{a} \beta_{0}\left[1-\left(1-t_{h}^{*}\right)^{\alpha}\right]$

Suppose that the NGO obtains external funds (from donations or grants), denoted with $F$, as well as the entire income derived from the conservation area (e.g. tourism revenue from the natural park), which we denote, per unit of carrying capacity, as $R$. Being a non-profit organization, the NGO has to satisfy the nondistribution constraint (see Hansmann, 1980), which states that it cannot distribute profits; in other words, its revenue has to be spent to cover its costs. Assume that the NGO proposes the payment $w^{\text {high }}$ that satisfies (12) with equality. Then, the nondistribution constraint of the NGO becomes

$Q R+F=2 w^{h i g h}=p_{h} Q-2 p_{a} \beta_{0}\left[1-\left(1-t_{h}^{*}\right)^{\alpha}\right]$.

In other words, the minimum amount of external funds that the NGO needs under complete contracts to implement efficient conservation is

$F_{\min }=Q\left(p_{h}-R\right)-2 p_{a} \beta_{0}\left[1-\left(1-t_{h}^{*}\right)^{\alpha}\right]$.

\subsection{Participatory conservation: The rationale and inefficiency}

Classic results in economic theory state that if contracts are incomplete, the ownership of productive assets matters crucially for efficiency (Grossman \& Hart, 1986; Besley \& Ghatak, 2001). In the settings on which we focus, the contracts between (Northern) NGOs and Southern beneficiaries are severely incomplete, because of both strong informational asymmetries and enforcement problems (Baland \& Platteau, 1996; Werker \& Ahmed, 2008).

This provides the main rationale for participatory conservation. If the NGO is the sole owner of the conservation area and all the income from the area accrues to the NGO, in the absence of complete contracts, the farmers have little interest in putting effort into the project. However, their effort (e.g. strongly reducing "hunting") is fundamental for the project's success. Plenty of empirical

\footnotetext{
${ }^{7}$ Given that the contracts are complete, the only individual-rationality constraint is the participation constraint (Laffont \& Martimort, 2002), i.e. an incentivecompatibility constraint is unnecessary, since the behavior is fully observable.
} 
evidence supports this by demonstrating the failure of "top-down" approaches in the management of protected areas, given the difficulty of effective monitoring and enforcement in developingcountry contexts (Galvin \& Haller, 2008; Garnett et al., 2007). The development practitioners generally agree that direct participation of project beneficiaries improves project performance (Ishamn, Naravan, \& Pritchett, 1995; Brosius et al. 2005). For these reasons, the NGO might prefer to transfer the property rights (although without the right to sell) over the conservation area to the local community, so as to provide the community members with the appropriate incentives to provide conservation effort. This transfer implies that the revenue (e.g. from tourism) accrues to the local community. Thus, the rest of our analysis relies on two elements of the same mechanism: (1) if the productivity of agriculture is sufficiently low, the farmers do not restrain hunting; (2) if the productivity in the agricultural sector increases sufficiently, the farmers start to put positive conservation effort (i.e. restrain hunting and contributing to project activities).

Substantial evidence supports both of these elements. Regarding the first, in the short run, the income from tourism in participatory conservation projects may not exceed the opportunity cost of land. This has been extensively documented by case studies of PC initiatives worldwide (for reviews, see Galvin \& Haller, 2008; Garnett et al., 2007). In areas in which the park-related tourism potential is low (for example, Western Africa), while sharing the benefits derived from natural parks and wildlife with local project beneficiaries has improved the revenue flows of the latter, the available evidence indicates that rural population loses out in economic terms when protected areas are established and wildlife becomes protected (Emerton, 2001; Muchapondwa, Carlssonyand, \& Köhlin, 2006; Vallino, 2009; Smith, Lynhamb, Sanchirico, \& Wilson, 2009; Coria \& Calfucura, 2012). Brown (1998: 4) states that "while one cannot entirely exclude tourism from the range of options open to governments wishing to promote conservation with development, its role can be easily overrated, and it is unlikely to provide the panacea for biodiversity conservation in many parts of Africa". In Western Africa, scholars have documented a number of structural shortcomings regarding nature and wildlife-based tourism. These include the severe lack of infrastructure, shortage of wild game as compared to Eastern and Southern Africa, and limited capacity of national and local governments to make significant investments in the tourism industry (Brown, 1998; Vallino, 2009). Moreover, some authors find that only a fraction of revenue from participatory conservation projects actually reaches the community members, further reducing the incentives for the local population to change their habits regarding hunting and harvesting (see Winkler, 2011; Barrett \& Arcese, 1995; Bookbinder, Dinerstein, Rijal, Cauley, \& Rajouria, 1998; Gibson \& Marks, 1995; Wells, Brandon, \& Hannah, 1992), while the rest going to the NGO to cover its operation expenses, and to the local government in the form of taxes, etc. (Calfucura, 2018).

Further considerations arise for the long run. First, although income from tourism increases in case the project is successful, the local population living close to subsistence may not be able to afford the possibility of deferring the satisfaction of basic needs to the future (Baland \& Platteau, 1996; Baland \& Francois, 2005; Dhakal et al., 2012). Baland and Platteau (1996: 19) state that “(...) agents who live close to their subsistence level and have no alternative income-earning opportunities, are concerned that the income they derive from exploitation of the resource meets their subsistence requirement in each period. If the conservation of the resource involves costly investments that have a long gestation period, it may happen that they are not able to bear such a sacrifice". This concern is closely linked to the broader issue of land management in such contexts (see, e.g., Calfucura, 2018). Vermeulen (2004) discusses the example of the Parc $W$ in West
Africa, where violent land disputes are frequent and food crops in agriculture already compete with cash crops, grazing, hunting and harvesting activities. He argues against adding a further land-intensive activity such as safari hunting for tourism, even if this latter would be conducted in a participatory way.

Second, income from agriculture is individual, whereas tourism income is usually channeled to the community as a whole and collective incentives may often be ineffective (Gibson, 1999; Hulme \& Murphree, 2001; Galvin \& Haller, 2008: 21; Smith et al., 2009). The creation of a community forest whose aim is commercial and tourism revenue for the benefit of the community often implies delimiting land areas on spaces that up to that point have been exploited and managed by individual households. This may create additional transaction costs, if the community does not have sufficiently developed institutional arrangements for decentralization and participation (Joiris \& Bigombé, 2008: 28; Borrini-Feyerabend, 2000).

Third, poor farmers in developing countries are usually highly risk averse. Tourism income is typically more volatile than the one from agriculture, because it is subject to the international fluctuations of the recreation industry (Barrett \& Arcese, 1995; Brown, 1998; Dansero, 2010: 434; Coria \& Calfucura, 2012). This might discourage local farmers from relying on tourism revenue as a reliable source of income. Sanjayan, Shen, and Jansen (1997) argue that "....indeed the income needs and expectations are not fixed at a certain level, and increased income derived from ICDPs (...) is frequently accepted by people in addition to, rather than in lieu of income derived from access to protected areas" (McShane \& Wells, 2004, p. 18).

Finally, as Barrett and Arcese (1995) identify, the lack of functioning of rural markets limits the effectiveness of monetary transfers from tourism. For cash transfers to be effective, local people must be able to exchange money for food or other consumption goods. However, in rural and remote areas, the opportunity of this exchange is often constrained by poor access to markets due to high transaction costs (Muller \& Albers, 2004; De Janvry, Fafchamps, \& Sadoulet, 1991).

In general the contradictions of the tourism revenue are shown in the two case studies presented in Section 2. In the Vietnamese Park tourism boomed because of the World Heritage status, while in the Burkinabé case touristic activities never raised at substantial level. Nevertheless, in the two examples livelihood problems related to the participatory conservation scheme were very similar, and so were the difficulties for the local community to both generate and absorb effectively the revenue from touristic activities.

Consider now the second key element of our mechanism, i.e., that the productivity increases in agriculture would induce farmers to devote more effort to conservation. We recall that it is assumed that agriculture takes place outside the conservation area, and what we label as "hunting", inside. Therefore if agricultural productivity increases, on the one hand "hunting" decreases and therefore there is higher possibility to conserve better the park; on the other hand farmers have more time to devote to conservation activity directly, as it is desired by the project scheme. This essentially relies on the well-known "Borlaug hypothesis", i.e. that increasing the productivity of agriculture on the best farmland can help control deforestation by reducing the demand for new farmland (Borlaug, 2000; Borlaug, 2007; see also Angelsen \& Kaimowitz, 2001a, 2001b). Agricultural intensification triggers two opposed forces, one that increases and another that reduces cultivated surfaces (Rudel et al., 2009). Intensified production allows farmers to have higher yields per hectare and thus a higher (gross) income, and this would induce farmers to expand the cultivated area. However, if demand for the food products is relatively inelastic, the increase in supply will result in a strong decline in crop prices and this effect may result in reduction of cultivated surface. The increased yields that set these processes in motion may 
have origins from changes in technology, but also from the knowledge that farmers accumulate about specific plots of land, since they would abandon their less-productive fields. The lands abandoned by farmers have the potential to become places that provide enhanced environmental services and face an increase in forest cover (Walker, 1993; Mather \& Needle, 1998; Waggoner \& Ausubel, 2001; Matson \& Vitousek, 2006; Borlaug, 2007; Pascual \& Martinez-Espineira, 2009; Baland, Libois, \& Mookherjee, 2018). On the contrary, if demand is sufficiently elastic, the increase in supply does not lead to a price decline and the overall incentive for higher production by using more land remains in place (Rudel et al., 2009). Empirical studies provide evidence for both land-consuming and land-sparing effects (Tachibana \& Nguyen, 2001; Pascual \& Barbier, 2006; Shively \& Martinez, 2001; Kaimowitz \& Smith, 2001; Coxhead, Shively, \& Shuai, 2001; Meyfroidt \& Lambin, 2007; Angelsen \& Kaimowitz, 2001a: 404407), depending on the context and on the type of technology applied $^{8}$. Finally, from the political point of view, Rudel et al. (2009) underline that "both reducing (...) deforestation (...) and [implementation of] payments for environmental services on abandoned agricultural lands only become politically acceptable policy options when crop yields rise on the remaining lands (...)".

Thus, our analysis is complementary to the findings by Deininger and Minten (1999) concerning the relation between deforestation and agricultural intensification in Mexico. They discovered that existing forms of communal agricultural land are not associated to high deforestation rates, that there is apparently no incompatibility between agricultural support policies and conservation objectives in the medium to long term, and that poverty influences negatively the forest cover. Therefore, as they argue, "policies that focus on natural resource conservation without concern for the socioeconomic well-being of the affected population may be seriously misguided" (ibid.: 336).

It is important to note that the positive effect of a support for agriculture does not lie only in the fact that this sector would become more productive than hunting, but is more general: if agricultural productivity increases and generates higher income, the profit derived from tourism could be always more a complement, rather than a substitute. With a higher overall income, farmers would bear better the costs of the efforts dedicated to the park.

Let us formalize the core of the above discussion in the framework of our simple model. Assume that the NGO has $F$ units of resources (external funds) and denote with $e$ the amount used for agricultural support (i.e. F-e are funds devoted to environmental conservation). The NGO expenses in agriculture will influence the net marginal benefit of hunting activity of the farmers, which, in turn, will influence the level of conservation and therefore the final outcome of the participatory conservation project.

The property over the conservation area is transferred to the farmers (collectively), i.e. they are the claimants of its revenues. We also assume that the output of the conservation area (e.g. quality and quantity of the environment/wildlife) is described by the Cobb-Douglas production function with NGO environmental expenses and the carrying capacity (net of hunting) as inputs: $(F-e)\left(Q-\gamma \sum t_{h}\right)$.

The agricultural productivity depends positively on the NGO's expenses for agricultural extension, and has the following form $\beta(e)=\beta_{0}+\beta_{1}(e)$, with $\beta_{1}^{\prime}>0$. Let's assume that the impact of agricultural extension expenses on the productivity is rather small (or zero) up to a certain level, and has the usual concave shape

\footnotetext{
${ }^{8}$ Angelsen and Kaimowitz (2001b) offer an excellent and detailed study on the links between improvements in agricultural techniques and consequent impact on the environment, on land management and on forest cover, both in developed and developing countries. For issues on land use transition and deforestation see also Lambin and Meyfroidt (2010).
}

afterwards. For instance, it can have the usual S-shaped form (similar to the one in Foster \& Rosenzweig, 1995; Feder, Just, \& Zilberman, 1985) or contain a non-divisibility. ${ }^{9}$

As before, the NGO's objective is to maximize conservation, i.e. $\operatorname{Min} \sum t_{h}(z)$. The timing of the game is: (1) the NGO commits the amount of resources $e$ to agriculture and the remaining part to the conservation; (2) the farmers observe $e$ and decide on their allocation of time between different activities.

Let's assume that the two farmers split the revenue from tourism equally. The utility-maximization program of farmer $A$ becomes:

$\operatorname{Max}_{t_{h}^{A}} p_{a} \beta(e)\left(t_{a}^{A}\right)^{\alpha}+p_{h} Q \frac{t_{h}^{A}}{t_{h}^{A}+t_{h}^{B}}+\frac{(F-e)\left(Q-\gamma \sum t_{h}\right) R}{2}$,

subject to $t_{a}^{A}+t_{h}^{A}=1$

Here, $R$ is the tourism revenue per unit of the production output of the natural park, and thus the last term in the objective function describes $A$ 's revenue from tourism.

The first-order condition of the corresponding unconstrainedoptimization problem becomes:

$$
\begin{aligned}
& p_{a} \beta_{0} \alpha\left(1-t_{h}^{A}\right)^{\alpha-1}+p_{a} \beta_{1}(e) \alpha\left(1-t_{h}^{A}\right)^{\alpha-1}+\frac{(F-e) R \gamma}{2} \\
& \quad=p_{h} Q \frac{t_{h}^{B}}{\left(t_{h}^{A}+t_{h}^{B}\right)^{2}}
\end{aligned}
$$

Let's denote with $t_{h}^{* N, e}$ the equilibrium (individual) level of hunting, when the NGO spends $e$ for agricultural extension. When $e=0$, i.e. the NGO devotes the whole amount of resources to conservation, the amount of hunting time that equates the marginal benefit of hunting to its marginal cost is high (Fig. 2). As $e$ increases, the marginal benefit of hunting (described by the right-hand side of (15)) does not change, whereas the marginal cost decreases (this is because the second term, the effect of agricultural extension expenses on the agricultural productivity increases only gradually, whereas the revenue from the natural park falls linearly). Consequently, equilibrium hunting $t_{h}^{* N, e}$ increases (as can be seen on Fig. 2).

Suppose that $e$ keeps increasing. Beyond a certain level (corresponding to point $e^{*}$ on Fig. 2), the effect of agricultural extension on productivity takes off and outweighs the linear fall in revenue from the natural park. Therefore, the marginal cost of hunting starts to increase, and the equilibrium (and total) hunting starts to decrease. Note that on Fig. 2, such a decrease passes by the point $\bar{e}$, where the total hunting is equal to the level of hunting under $e=0$. In other words, any agricultural-extension spending by the NGO below the level $\bar{e}$ is counter-productive. ${ }^{10}$

As $e$ increases further, the decrease in equilibrium hunting continues until the point where the diminishing marginal returns to agricultural-extension bite sufficiently strongly. This is the level

\footnotetext{
${ }^{9}$ The related literature shows that when a new technology in agricultural environment is introduced, at the initial stage it encounters significant barriers to adoption and impacts arise only after a given period, for diverse reasons: farmers have imperfect knowledge of the new technology; economies of scale derived from accumulation of experience with the new technology do not emerge immediately; farmers may be discouraged by the initial low economic impact of the agricultural innovation (Feder et al., 1985, Foster \& Rosenzweig, 1995). In any case, our main result (concerning the effect of donor financing) holds even for the everywhere concave function $\beta_{1}(e)$. The above assumptions on the shape of the functional form serve to show our result more starkly.

10 The case of GEPRENAF Project in Burkina Faso illustrates this very clearly. This project had planned some activities for support to the agriculture, but was been implemented with insufficient intensity. It thus created unfulfilled expectations in the local population and resulted in counter-productive effects, as documented in Vallino (2009).
} 


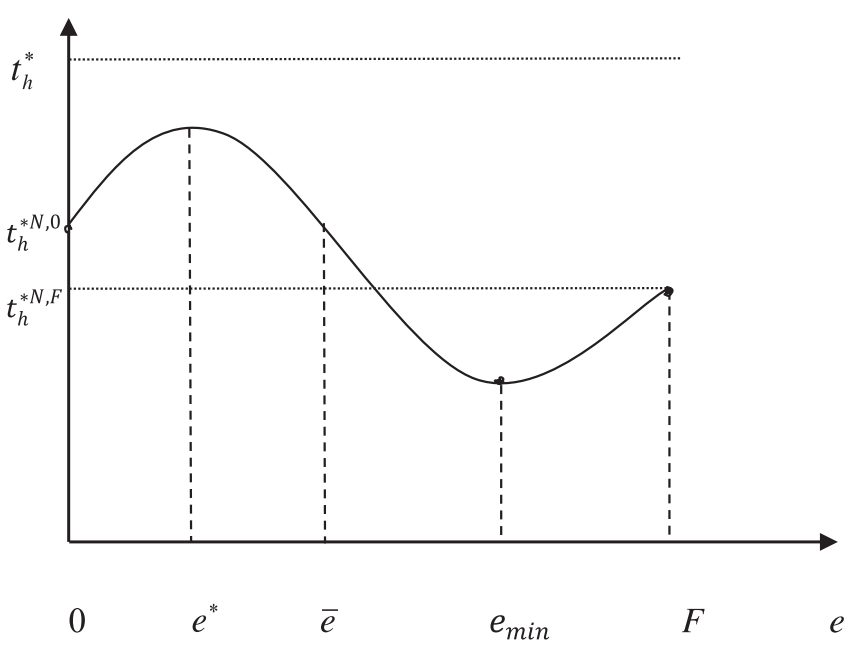

Fig. 2. NGO's allocation of funds and equilibrium hunting.

where the equilibrium hunting is minimized (corresponding to point $e_{\min }$ on Fig. 2). Beyond this point, the equilibrium hunting starts to increase again.

Our analysis thus immediately implies the following result:

Proposition 2. An institutional constraint blocking the conservationoriented NGO from spending on supporting agriculture $(e=0)$ implies a sub-optimal level of effective conservation (i.e. inefficiently high level of hunting).

Next, let's compare the first-order conditions of farmers, with and without the NGO intervention. Consider first the case in which $e=0$, i.e. the extreme case in which the NGO creates the conservation area but does not spend anything for agricultural extension. Compare expressions (15') for $e=0$ and (3):

(With NGO, under $e=0): p_{a} \beta_{0} \alpha\left(1-t_{h}^{A}\right)^{\alpha-1}+\frac{F R \gamma}{2}=p_{h} Q \frac{t_{h}^{B}}{\left(t_{h}^{A}+t_{h}^{B}\right)^{2}}$

$$
\text { (Without NGO) : } p_{a} \beta_{0} \alpha\left(1-t_{h}^{A}\right)^{\alpha-1}=p_{h} Q \frac{t_{h}^{B}}{\left(t_{h}^{A}+t_{h}^{B}\right)^{2}}
$$

We see that the marginal benefit in the two expressions coincides, while the marginal cost is higher in the setting with the NGO intervention. Consequently, the level of hunting in the situation with the NGO intervention but no expenses in agricultural extension $(e=0), t_{h}^{* N, 0}$, is lower than the total hunting in the absence of the NGO, $t_{h}^{*}$.

Consider now the corresponding first-order conditions in the opposite extreme case (with the NGO spending everything for the agricultural extension):

$$
\begin{aligned}
(\text { With NGO, under } e=F) & : p_{a} \beta_{0} \alpha\left(1-t_{h}^{A}\right)^{\alpha-1}+p_{a} \beta_{1}(F) \alpha\left(1-t_{h}^{A}\right)^{\alpha-1} \\
& =p_{h} Q \frac{t_{h}^{B}}{\left(t_{h}^{A}+t_{h}^{B}\right)^{2}} .
\end{aligned}
$$

Again, the marginal benefit of hunting is the same with and without NGO intervention, while the marginal cost is higher in the situation with the NGO. Consequently, the total hunting when the NGO intervenes and spends everything for agricultural extension, $t_{h}^{* N, F}$, is also lower than in the situation without the NGO.

Finally, comparing the first-order conditions under $e=0$ to the one under $e=F$, we observe that the total hunting might be higher or lower in the former case as compared to the latter. This depends on the magnitudes of $R, p_{a}$, and $\gamma$ : if the unit revenue from tourism
$(R)$ or the damage from hunting for the natural park $(\gamma)$ is sufficiently low, or the likelihood of the good harvest is sufficiently high $\left(p_{a}\right)$, the total hunting under the purely conservation project $\left(t_{h}^{* N, 0}\right)$ is higher than in the pure agricultural extension project, $t_{h}^{* N, 0}$ (but is still lower than in the absence of the NGO of any project type, $t_{h}^{*}$ ). The opposite is true if $R$ or $\gamma$ is sufficiently high, or if $p_{a}$ is sufficiently low.

It is important to note that multiple authors argued about the importance of allowing conservation NGOs to spend sufficient resources to indirect activities of the project such as agricultural extension. For instance, Garnett et al. (2007) state: "when people are living in extreme poverty, it will usually be more important to invest in their health and education and in the productivity of their agriculture than in the protection of their forests... ICDPs [participatory-conservation projects] have to be based upon an understanding of the states and trends of the capital assets of the concerned populations, and ... should be made in ways that lead to balanced and sustainable improvements". Similarly, Brown (1998) explains that the shortfall of income from the alternative income-generating activities feeds hostility by local farmers towards the project and, consequently, increasing the level of NGO investment in enhancing the productivity from the main sources of income (such as agriculture) may effectively limit the external costs of conservation area management.

Given these considerations, one may wonder why the conservation NGOs are often so reluctant to invest in agricultural extension. One plausible hypothesis is that their funding comes from sources (e.g. private donors in the North) that may be unhappy to know that the NGO spends a part of the donations to activities different from conservation. This might represent an institutional constraint that discourages the NGO from moving away from $e=0$ allocation. The next subsection analyzes this possibility in detail.

\subsection{Donor discouragement and NGO's dilemma}

The conservation-oriented NGO is typically strictly tied to its mission, and its donors might strictly link their (current and future) donations to spending the funds of the NGO exclusively for conservation (Garnett et al., 2007; Werker \& Ahmed, 2008; Azam \& Laffont, 2003). The NGO therefore faces the dilemma: if it splits its resources between the natural park and agricultural extension, the conservation effort of the local community would be higher, but it risks to alienate its (conservation-motivated) donors. Conversely, investing all of the resources to the park would lead to a large park, but with little conservation effort of the local community, which might increase the risk of failure in the long run.

This dilemma emerges because of the donors' narrow view of local implications of strict environmental policies in poor rural areas of developing countries. In part, such view is itself related to the recent increase in the size and power of international conservation-oriented organizations, which were instrumental in bringing politics into nature-caring issues (Alcorn, 2005; Adams \& Hutton, 2007). ${ }^{11}$ Both the NGOs and governmental organizations which were focused on local or rural development and on community participation realized that they had to broaden their focus and to include environmental concerns into their programs to keep obtaining funding (Garnett et al., 2007; Campbell \& Vainio-Mattila, 2003; Giannini, 2011). Angelsen and Kaimowitz (2001b: 403-404) write that "[a] reason why policy-makers should understand how technological change affects forests is that research managers and development agencies increasingly seek to justify their budgets by

\footnotetext{
11 For a nice historical perspective on conservation movements and participatory conservation initiatives, see Alcorn (2005) and Brosius et al. (2005).
} 
claiming that their projects help conserve forests. As the world becomes increasingly urban and past scientific breakthroughs allow us to produce more food than markets demand, political support for agricultural research and technology transfer has declined. In contrast, public concern about the environment, and tropical forests in particular, has never been stronger".

Surprising as it may be, most (small) donors are strongly attached to their preferred NGO projects and are unwilling to "trade" the non-targeted use of their funds for the broader project efficiency. It is likely that the core donors of a conservationoriented NGO have environmental motivations and may be more tied, for example, to the protection of certain charismatic species (Tisdell, 2007) or to clear earmarking of resources dedicated to conservation (Frontuto, Dalmazzone, Vallino, \& Giaccaria, 2017) than to a more comprehensive socio-ecological dimension. Therefore, the "warm-glow" feeling that the donors obtain from contributing to the NGO typically increases with the size of the created protected area, and they have relatively low concern for the degree of cooperation from the indigenous community (Garnett et al., 2007; Azam \& Laffont, 2003). Consequently, the NGO faces a strong incentive to invest more into the natural park than into agriculture. The use of participatory techniques for conservation in order to motivate local population to conserve frequently often becomes a pure rhetoric, which "upon occasion served to help shift resource away from local strategies for livelihood and empowerment toward resource management that serves more powerful institutional interests (...)" and triggered "processes of expropriation, reallocation, and management in which political and economic inequalities are (...) reinforced by programs legitimized through the language of participatory resource" (Brosius \& Lowenhaupt-Tsing, 1998: 6; see also Blaikie, 2006; Adams \& Hutton, 2007). In addition, in the context of the rising competition between NGOs for funding (Aldashev \& Verdier, 2010; 2018), most conservation NGOs feel that the risk of alienating their conservation-oriented donors by assuming a more pragmatic mixed approach is just too high.

To analyze this problem, we extend the model of the previous section, by endogenizing the funding of the NGO as follows. Consider a continuum of size 1 of small (atomistic) donors that care about environment, and denote an individual donor with $i$. Each donor has an (indivisible) unit of resource. Consuming this resource provides the donor with utility $\underline{u}$, whereas donating it to the conservation NGO gives the donor the level of utility $u(e)$ $G_{i}$, where $G_{i}$ is the individual characteristic capturing the intensity of warm-glow utility of giving, which we assume for simplicity to be randomly uniformly distributed on the interval $[0,1]$. To capture the idea that donors are alienated by NGO expenditures to nonconservation activities, we assume $u^{\prime}(e)<0$. Also, let the NGO have its own funds (or funds coming from unconditional government grants) equal to $F_{0}$.

The timing of the game is as follows:

(1) the NGO commits to how it plans to allocate its resources between conservation and agricultural extension (choice of e);

(2) Each donor $i$ decides on whether to give its unit of resource to the NGO or to consume it;

(3) the NGO uses the collected funds to create the natural park, and transfers the ownership to farmers. Each farmer decides on its allocation of time between hunting and agriculture.

We solve the game by backward induction. At stage (3), the farmers' decision concerning the allocation of time is described by the first-order condition (15), and thus the level of hunting is $t_{h}^{* N, e}$. At stage (2), the donors that decide to give to the NGO are those for whom the condition $\underline{u} \leq u(e) G_{i}$ holds. Given the uniform distribution assumption, this means that the mass of donors (and total donations) equals $1-\frac{u}{u(e)}$.

This implies that at stage (1) the total funds that NGO can raise is

$F=F_{0}+1-\frac{\underline{u}}{u(e)}$.

Note that the total funds of the NGO are now decreasing in its expenditures for agricultural extension:

$\frac{\partial F}{\partial e}=\frac{\underline{u}}{[u(e)]^{2}} u^{\prime}(e)<0$.

This represents the institutional constraint that we mentioned above, and where $u^{\prime}(e)$ represents how strictly conservationists are the donors, i.e. how harshly the donors penalize the NGO for using funds beyond its narrow mission.

At stage (1), the problem of the NGO now becomes:

$\operatorname{Min} \sum t_{h}^{* N, e}(e)$ subject to (15) and (16).

The solution of this problem is described by Fig. 3. Let the NGO commit at stage 1 to no spending for agricultural extension $(e=0)$. It would then collect the amount of funds equal to $F(0)$. The (hypothetical) total hunting curve (describing total hunting as a function of $e$ ) corresponding to this amount of funds is the lowest in the family of curves on Fig. 3 , and the point $A$ (corresponding to the level $e=0$ ) is the resulting equilibrium in the subsequent game. Suppose instead the NGO commits to the level $e=e_{1}$. The amount of funds it collects would fall to $F\left(e_{1}\right)$. The (hypothetical) total hunting curve corresponding to funds $F\left(e_{1}\right)$ lies a bit above, as the reduction of the funds would constrain the NGO to carry out a smaller project. Point $B$ (corresponding to the level $e=e_{1}$ ) is the resulting equilibrium in the subsequent game. In the analogous manner, we construct the points $C, D$, and $E$. The NGO's optimal decision at stage 1 thus implies choosing the level of $e$ corresponding to the lowest point on the resulting curve $T_{h}^{*}(e)$, which for the case described by Fig. 3 corresponds to level $e=e_{3}$.

Clearly, how rapidly the (hypothetical) total hunting curve shifts up is determined by the degree of conservationism of the donors, $u^{\prime}(e)$. We thus obtain the following.

Proposition 3. (a) If the donors are mildly conservationist (i.e. the penalty $u^{\prime}(e)$ imposed on the NGO for deviating from its narrow mission is sufficiently small), the NGO uses a part of its funds to increase the productivity of agriculture $(e>0)$. The conservation area is smaller than the maximum that the NGO can create, but the total

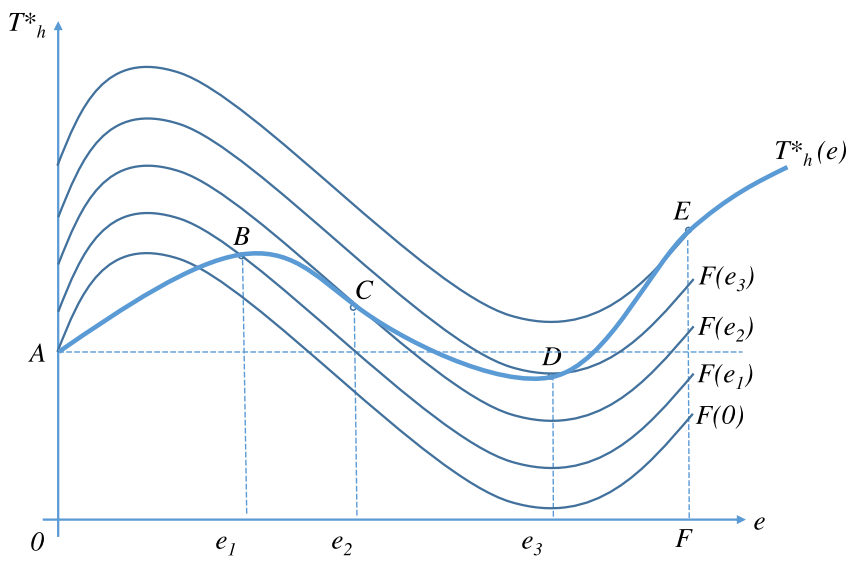

Fig. 3. Endogenous NGO funds and total hunting. 
hunting is effectively restrained. (b) If the donors are strictly conservationist (i.e. the penalty $u^{\prime}(e)$ imposed on the NGO for deviating from its narrow mission is sufficiently large), the NGO uses all of its funds for conservation $(e=0)$. The conservation area is the maximum that the $N G O$ can create, but the total hunting is relatively poorly restrained.

\section{Conclusion}

Participatory conservation is a powerful concept that has been designed in national and international development programs, based on the goal of combining economic development with nature conservation. One of the pillars of this concept is direct involvement of local communities in conservation activities. This paper has developed a theoretical model that links the rationale for participatory conservation, the mechanisms behind its inefficiencies in terms of nature conservation, and the institutional difficulties encountered by conservation NGOs in balancing between the optimal approach to conservation and the risk of donor discouragement. Our main finding is that, ideally, the conservationoriented NGO must deviate from its narrow mission in order to reach it, which puts the $\mathrm{NGO}$ in front of a dilemma. On the one hand, the NGO might have an incentive to invest into agricultural extension (which would generate incentives for the local community to collaborate more actively in conservation efforts); on the other, the NGO must stick to its narrow environmental mission in order to secure funding from its environmental-oriented donors.

Intuitively, the revenue from tourism plays the key role for the main mechanism of the model. Higher revenue would naturally reduce the inefficiency; however, this may still not completely solve the problem. In a wider sense, effective conservation projects should invest in "enhancing, rather than replacing, existing livelihoods" (Brown, 1998: 4), i.e. should provide tourism revenue as a complement (rather than a substitute) to the existing income flows of the community. Since tourism may be highly volatile in some contexts, due to a combination of factors such as variability of valuable natural features and species, lack of infrastructure, political instability, it should not be considered as the main source of socio-economic development of indigenous communities. Numerous development practitioners have highlighted that income from participatory conservation should not be a substitute for broader commitment by NGOs and government agencies to address the basic problems and demands faced by local communities (Garnett et al., 2007; Berkes, 2007; Coria \& Calfucura, 2012).

More generally, our analysis contributes to understanding the consequences of the decentralized organization of development cooperation, of which this study is an example in an environmental context. One major characteristic of such organization, namely competition for donations, has been already analyzed quite extensively (see Aldashev \& Verdier, 2010; Ghosh \& Van Tassel, 2012; Heyes \& Martin, 2016; Aldashev, Marini, \& Verdier, 2017; among others). The analysis in this paper illustrates that another major feature, namely "upstream" accountability of NGOs (i.e. towards donors and not towards beneficiaries), might also be a key source of inefficiency in the functioning of development cooperation.

\section{Declaration of Competing Interest}

Authors declare no conflicts of interest.

\section{Acknowledgments}

We thank Jean-Philippe Platteau, Thierry Verdier, Stephen Salant, Bard Harstad, Antony Heyes, Thomas Lyon, Hélène Ollivier, Petros Sekeris, Raphael Soubeyran, Iftikhar Lodhi, Cédric Vermeulen, Silvana Dalmazzone, Cecilia Navarra, Vittorio Valli, Donatella
Saccone, and Francesco Laio. We appreciated the feedbacks from the participants at the ESNIE Summer School, the IAERE Conference, the N.G.O. (Nonprofits, Governments, Organizations) Workshop in Warwick, the GREENGO Workshop in Paris, the Sustainability and Development Conference at the University of Michigan. We are grateful to the Turin Center on Emerging Economies (Collegio Carlo Alberto and Compagnia di Sanpaolo) and to the project "Coping with water scarcity in a globalized world" (ERC-2014_CoG, project 647473, Politecnico of Torino) for financial support. Finally, we thank the Editor and two anonymous reviewers for valuable comments that contributed to the improvement of the manuscript.

\section{References}

Adams, W. M., \& Hutton, J. (2007). People, parks and poverty: Political ecology and biodiversity conservation. Conservation and Society, 5(2), 147-183.

Agrawal, A. (2007). Forest, governance and sustainability: Common property theory and its contributions. International Journal of the Commons, 1(1), 111-136.

Agrawal, A., Hajjar, R., Liao, C., Rasmussen, L. V., \& Watkins, C. (2018). Editorial overview: Forest governance interventions for sustainability through information, incentives, and institutions. Current Opinion in Environmental Sustainability, 32, 1-7.

Alcorn, J. B. (2005). Dances around the fire: Conservation organizations and community-based natural resource management. In J. P. Brosius, A Lowenhaupt Tsing, \& C. Zerner (Eds.), Communities and conservation: Histories and politics of community-based natural resource management. Walnut Creek, CA: Altamira Press.

Aldashev, G., \& Navarra, C. (2018). Development NGOs: Basic facts. Annals of Public and Cooperative Economics, 89(1), 125-155.

Aldashev, G., \& Verdier, T. (2010). Goodwill bazaar: NGO competition and giving to development. Journal of Development Economics, 91(1), 48-63.

Aldashev, G., Marini, M., \& Verdier, T. (2017). Samaritan bundles: Inefficient clustering in NGO Projects. CEPR Discussion Paper. 11931.

Alix-Garcia, J. (2008). An exploration of the positive effect of inequality on common property forests. Journal of Development Economics, 87(1), 92-105.

Angelsen, A., \& Kaimowitz, D. (2001a). When does technological change in agriculture promote deforestation? In D. R. Lee \& C. B. Barrett (Eds.), Tradeoffs or synergies? Agricultural intensification, economic development and the environment. Wallingford, UK, New York: CAB International.

Angelsen, A., \& Kaimowitz, D. (2001b). Agricultural technology and forests: A recapitulation. In A. Angelsen \& D. Kaimowitz (Eds.), Agricultural technologies and tropical deforestation. Wallington, Oxon, New York: CAB International. and Center for International Forestry Research (CIFOR), Jakarta.

Auer, M. (2006). Contexts, multiple methods and values in the study of common pool resources. Journal of Policy Analysis and Management, 25(1), 215-227.

Azam, J. P., \& Laffont, J.-J. (2003). Contracting for aid. Journal of Development Economics, 70(1), 25-58.

Baland, J. M., \& Francois, P. (2005). Commons as insurance and the welfare impact of privatization. Journal of Public Economics, 89, 211-231.

Baland, J. M., \& Platteau, J. P. (1996). Halting degradation of natural resources. Is there a role for rural communities? Oxford: Clarendon Press.

Baland, J. M., Libois, F., \& Mookherjee, D. (2018). Forest degradation and economic growth in Nepal, 2003-2010. Journal of the Association of Environmental and Resource Economists, 5(2), 401-439.

Balint, P. (2006). The decline of a model community-based conservation project: Governance, capacity, and devolution in Mahenye, Zimbabwe. Geoforum, 37(5), 805-815.

Banque Mondiale (2000). Rapport d'Evaluation Externe du Projet de Gestion Participative des Ressources Naturelles et de la Faune. Ouagadougou, Burkina Faso: Volet Burkina Faso.

Barrett, C., \& Arcese, P. (1995). Are integrated conservation-development projects (ICDPs) sustainable? On the conservation of large mammals in sub-Saharan Africa. World Development, 23, 1073-1084.

Barrett, C. B., \& Arcese, P. (1998). Wildlife harvest in integrated conservation and development projects: Linking harvest to household demand, agricultural production, and environmental shocks in the Serengeti. Land Economics, 449-465.

Berkes, F. (2007). Community-based conservation in a globalized world. Proceedings of the National Academy of Sciences of the USA (PNAS), 104(39), 15188-15193.

Besley, T., \& Ghatak, M. (2001). Government versus private ownership of public goods. The Quarterly Journal of Economics, 116(4), 1343-1372.

Bixler, R. P., Dell'Angelo, J., Mfune, O., \& Roba, H. (2015). The political ecology of participatory conservation: Institutions and discourse. Journal of Political Ecology, 22(1), 164-182.

Blaikie, P. (2006). Is small really beautiful? Community-based natural resource management in Malawi and Botswana. World Development, 34(11), 1942-1957.

Bookbinder, M., Dinerstein, E., Rijal, A., Cauley, H., \& Rajouria, A. (1998). Ecotourism's support of biodiversity conservation. Conservation Biology, 12, 1399-1404. 
Borlaug, N. E. (2000). Ending world hunger: The promise of biotechnology and the threat of antiscience zealotry. Plant Physiology, 124, 487-490.

Borlaug, N. E. (2007). Feeding a hungry world. Science, 318, 359.

Borrini-Feyerabend, G. (2000). Co-management of natural resources: Organizing, negotiating and learning by doing. Yaoundé, Cameroon: International Union for the Conservation of Nature (IUCN), Regional Office for Central Africa (ROCA).

Bouamrane, M., Spierenburg, M., Agrawal, A., Boureima, A., Cormier-Salem, M. C. Etienne, M., \& Mathevet, R. (2016). Stakeholder engagement and biodiversity conservation challenges in social-ecological systems: Some insights from biosphere reserves in western Africa and France. Ecology and Society, 21(4).

Brockington, D., Scholfield, K., \& Ladle, R. (2018). Learning from a sectoral approach to the study of NGOs. In P. B. Larsen \& D. Brockington (Eds.), Anthropology of Conservation NGOs. Springer Verlag.

Brosius, J. P., Lowenhaupt, Tsing A., \& Zerner, C. (Eds.). (2005). Communities and conservation: histories and politics of community-based natural resource management. Walnut Creek, CA: Altamira Press.

Brosius, J. P., \& Lowenhaupt-Tsing, A. (1998). Representing communities: Histories and politics of community based resource management. Society $\mathcal{E}$ Natural Resources, 11(2), 157-168.

Brown, D. (1998). Participatory biodiversity conservation: rethinking the strategy in the low tourist potential areas of tropical Africa Natural Resource Perspectives No 33. London: Overseas Development Institute.

Bulte, E., \& van Soest, D. (2001). Environmental degradation in developing countries: Households and the (reverse) Environmental Kuznets Curve. Journal of Development Economics, 65(1), 225-235.

Calfucura, E. (2018). Governance, land and distribution: A discussion on the politica economy of community-based conservation. Ecological Economics, 145, 18-26.

Campbell, L. M., \& Vainio-Mattila, A. (2003). Participatory development and community-based conservation: Opportunities missed for lessons learned? Human Ecology, 31, 417-436.

Child, B., \& Dalal-Clayton, B. (2004). Transforming approaches to CBNRM: Learning from the Luangwa experience in Zambia. In T. O. McShane \& M. P. Wells (Eds.), Getting biodiversity projects to work: Towards better conservation and development (pp. 256-289). New York, New York, USA: Columbia University Press.

Coria, J., \& Calfucura, E. (2012). Ecotourism and the development of indigenous communities: The good, the bad, and the ugly. Ecological Economics, 73, 47-55.

Coxhead, I., Shively, G., \& Shuai, X. (2001). Agricultural development policies and land expansion in a southern Philippine watershed. In A. Angelsen \& D. Kaimowitz (Eds.), Agricultural technologies and tropical deforestation (pp. 347-365). Wallingford, UK: CABI International.

Dansero, E. (Ed.). (2010). Cooperazione decentrata, protezione della natura e pratiche territoriali: rappresentazioni a confronto tra Nord e Sud del mondo. Un'indagine a partire dall'analisi delle esperienze di partenariato tra aree protette del Piemonte e della Valle d'Aosta con $i$ PVS. Fondazione CRT - Progetto Alfieri; Dipartimento Interateneo Territorio, Politecnico e Università di Torino; Regione Piemonte Settore Aree Protette; Università della Valle d'Aosta.

De Janvry, A., Fafchamps, M., \& Sadoulet, E. (1991). Peasant household behavior with missing markets: Some paradoxes explain. Economic Journal, 101(1991), 1400-1417.

Deininger, K. W., \& Minten, B. (1999). Poverty, policies, and deforestation: The case of Mexico. Economic Development and Cultural Change, 47(2), 313-344.

Dhakal, B., Bigsby, H., \& Cullen, R. (2012). Socioeconomic impacts of public forest policies on heterogeneous agricultural households. Environmental and Resource Economics, 53(1), 73-95.

Dolsak, N., \& Ostrom, E. (2003). The commons in the new millennium: Challenges and adaptation. Cambridge: The MIT Press.

Duffy, R. (2006). Global environmental governance and the politics of ecotourism in Madagascar. Journal of Ecotourism, 5(1,2), 128-144.

Edmonds, E. V. (2002). Government-initiated community resource management and local resource extraction from Nepal's forests. Journal of Development Economics, 68(1), 89-115.

Emerton, L. (2001). The nature of benefits and benefits of nature: Why wildlife conservation has not economically benefited communities in Africa. In D. Hulme \& M. Muphree (Eds.), African wildlife and livelihoods: The promise and performance of community conservation. Harare: Weaver Press.

Engel, S., \& Palmer, C. (2008). Payments for environmental services as an alternative to logging under weak property rights: The case of Indonesia. Ecological Economics, 65(4), 799-809.

Fairhead, J., \& Leach, M. (1996). Misreading the African landscape. Society and ecology in a forest - Savanna mosaic. Cambridge University Press.

Feder, G., Just, R. E., \& Zilberman, D. (1985). Adoption of agricultural innovations in developing countries: A survey. Economic Development and Cultural Change, 33 (2), 255-298.

Ferraro, P. (2001). Global habitat protection: Limitations of development interventions and a role for conservation performance payments. Conservation Biology, 15, 990-1000.

Fischer, C., Muchapondwa, E., \& Sterner T. (2011). A bio-economic model of community incentives for wildlife management under CAMPFIRE. Environmental and Resource Economics, 48(2), 303-319.

Foster, A. D., \& Rosenzweig, M. R. (1995). Learning by doing and learning from others: Human capital and technical change in agriculture. Journal of Political Economy, 103(6), 1176-1209.

Franks, P., \& Blomley, T. (2004). Fitting ICDP into a project framework: A CARE perspective. In T. O. McShane \& M. P. Wells (Eds.), Getting biodiversity projects to work: Towards better conservation and development (pp. 77-97). New York: Columbia University Press.

Frontuto, V., Dalmazzone, S., Vallino, E., \& Giaccaria, S. (2017). Earmarking conservation: Further inquiry on scope effects in stated preference methods applied to nature-based tourism. Tourism Management, 60, 130-139.

Galvin, M., \& Haller, T. (Eds.). (2008). People, protected areas and global change: participatory conservation in Latin America, Africa, Asia and Europe. Swiss National Centre of Competence in Research (NCCR) North-South, University of Bern.

Garnett, S. T., Sayer, J., \& Du Toit, J. (2007). Improving the effectiveness of interventions to balance conservation and development: A conceptual framework. Ecology and Society, 12(1), 2.

Gasteyer, S., Flora, C. B., Fernández-Baca, E., Banerji, D., Bastian, S., Aleman, S., Kroma, M., Meares, A. (2016). Community participation for conservation and development of natural resources: A summary of literature and report of research findings. https://vtechworks.lib.vt.edu/handle/10919/65279.

GEPRENAF (1997). Diagnostic Conjoint Initial des Villages de la Zone d'intervention $d u$ Projet GEPRENAF. Banfora, Burkina Faso: Projet de Gestion Participative des Ressources Naturelles et de la Faune.

Ghosh, S., \& Van Tassel, E. (2011). Microfinance and competition for external funding. Economics Letters, 112(2), 168-170.

Giannini, V. (2011). REDD and International Organizations Working Paper No 545. Venezia: Fondazione Eni Enrico Mattei.

Gibson, C. C. (1999). Politicians and poachers: The political economy of wildlife policy in Africa. Cambridge University Press.

Gibson, C. C., \& Marks, S. (1995). Transforming rural hunters into conservationists: An assessment of community-based wildlife management programs in Africa. World Development, 23, 941-957.

Gordon, S. H. (1954). The economic theory of a common-property resource: The fishery. The Journal of Political Economy, 62(2), 124-142.

Grossman, S. J., \& Hart, O. D. (1986). The costs and benefits of ownership: A theory of vertical and lateral integration. Journal of political economy, 94(4), 691-719.

Hansmann, H. (1980). The role of nonprofit enterprise. The Yale Law Journal, 89(5), 835-901.

Hardin, G. (1968). The tragedy of the commons. Science, 162, 1243-1248.

Herrold-Menzies, M. (2006). Integrating conservation and development: What we can learn from Caohai, China. Journal of Environment and Development, 15(4), 382-406.

Heyes, A., \& Martin, S. (2016). Social labeling by competing NGOs: A model with multiple issues and entry. Management Science, 63(6), 1800-1813.

Hsing-Sheng, T. (2007). Development through conservation: An institutional analysis of indigenous community-based conservation in Taiwan. World Development, 35(7), 1186-1203.

Hughes, R., \& Flintan, F. (2001). Integrating conservation and development experience: $A$ review and bibliography of the ICDP literature. London: International Institute for Environment and Development (IIED).

Hulme, D., \& Murphree, M. (Eds.). (2001). African wildlife and livelihoods: The promise and performance of community conservation. Oxford and Portsmouth: James Currey and Heinemann.

Ishamn, J., Naravan, D., \& Pritchett, L. (1995). Does participation improve performance? Establishing causality with subjective data. The World Bank Economic Review, 9(2), 175-200.

Johannesen, A. B., \& Skonhoft, A. (2005a). Tourism, poaching and wildlife conservation: What can integrated conservation and development projects accomplish? Resource and Energy Economics, 27, 208-226.

Johannesen, A. B., \& Skonhoft, A. (2005b). Tourism, poaching and wildlife conservation: What can integrated conservation and development projects accomplish? Resource and Energy Economics, 27(3), 208-226.

Joiris, D. V., \& Bigombé, Logo P. (2008). Dynamiques participatives et développement local dans le Bassin congolais. Des rendez-vous manqués ? In P. A. Roulet \& P. Assenmaker (Eds.), Gouvernance et environnement en Afrique Centrale: le modèle participatif en question. Tervuren, Belgium: Musée Royale de l'Afrique Centrale.

Kaimowitz, D., \& Smith, J. (2001). Soybean technology and the loss of natural vegetation in Brazil and Bolivia. In A. Angelsen \& D. Kaimowitz (Eds.) Agricultural technologies and tropical deforestation (pp. 195-211). Wallingford, UK: CABI International.

Kideghesho, J. R. (2008). Who pays for wildlife conservation in Tanzania and who benefits? 12th Biennal Conference of the International Association of the Study of the Commons, Cheltenham, England, 14-18 July 2008.

Koop, G., \& Lise, Tole L. (1999). Is there an environmental Kuznets curve for deforestation? Journal of Development Economics, 58(1), 231-244.

Kovács, E., Fabók, V., Kalóczkai, Á., \& Hansen, H. P. (2016). Towards understanding and resolving the conflict related to the Eastern Imperial Eagle (Aquila heliaca) conservation with participatory management planning. Land Use Policy, 54, 158-168.

Laffont, J. J., \& Martimort, D. (2002). The theory of incentives: The principal-agent model. Princeton University Press.

Lambin, E. F., \& Meyfroidt, P. (2010). Land use transitions: Socio-ecological feedback versus socio-economic change. Land Use Policy, 27, 108-118.

Larsen, P. B. (2008). Linking livelihoods and protected area conservation in Vietnam: Phong Nha Kẻ Bàng World Heritage, local futures? In M. Galvin \& T. Haller (Eds.), People, protected areas and global change: participatory conservation in Latin America, Africa, Asia and Europe Perspectives of the Swiss National Centre of Competence in Research (NCCR) North-South, University of Bern (pp. 431-470). Bern: Geographica Bernensia. 
Larsen, P. B., \& Brockington, D. (2018). Anthropology of Conservation NGOs. Springer Verlag.

Lees, A. (2007). Review and analysis of Fiji's conservation sector. Waitakere City: The Austral Foundation.

Mansuri, G., \& Rao, V. (2004). Community-based and -driven development: A critical review. The World Bank Research Observer, 19(1), 1-39.

Mather, A., \& Needle, C. (1998). The forest transition: A theoretical basis. Area, 30, 117-124.

Matson, P. A., \& Vitousek, P. M. (2006). Agricultural intensification: Will land spared from farming be land spared for nature? Conservation Biology, 20, 709-710.

McShane, T. O., \& Wells, M. P. (Eds.). (2004). Getting biodiversity projects to work: towards more effective conservation and development. Columbia University Press.

Meyfroidt, P., \& Lambin, E. F. (2007). The causes of reforestation in Vietnam. Land Use Policy, 25, 182-197.

Muchapondwa, E., Carlssonyand, F., \& Köhlin, G. (2006). Can local communities in Zimbabwe be trusted with wildlife management? Evidence from contingent valuation of elephants Working Paper in Economics, No 395. University of Gothenburg.

Muller, J., \& Albers, H. J. (2004). Enforcement, payments, and development projects near protected areas: How the market setting determines what works where. Resource and Energy Economics, 26(2), 185-204.

Murphree, M. W. (2002). Protected areas and the commons. The Common Property Resource Digest. n.60.

Nuesiri, E. O. (2017). Feigning democracy: Performing representation in the UNREDD funded Nigeria-REDD Programme. Conservation and Society, 15(4), 384.

Oates, J. F. (1999). Myth and reality in the rain forest. How conservation strategies are failing in West Africa. Berkeley, CA: University of California Press.

Ostrom, E. (1990). Governing the commons. The evolution of institutions for collective action. Cambridge University Press.

Pascual, U., \& Barbier, E. B. (2006). Deprived land-use intensification in shifting cultivation: The population pressure hypothesis revisited. Agricultural Economics, 34, 155-165.

Pascual, U., \& Martinez-Espineira, R. (2009). The effect of environmental change and price policies on livelihoods in tropical agroforestry systems. Journal of International Development, 21, 433-446.

Perez-Castrillo, J. D., \& Verdier, T. (1992). A general analysis of rent-seeking games. Public Choice, 73(3), 335-350.

Platteau, J.-P., \& Gaspart, F. (2003). The risk of resource misappropriation in community-driven development. World Development, 31(10), 1687-1703.

Platteau, J.-P., \& Abraham, A. (2002). Participatory development in the presence of endogenous community imperfections. The Journal of Development Studies, 39 (2), 104-136.

Platteau, J.-P., \& Seki, E. (2007). Heterogeneity, social esteem and feasibility of collective action. Journal of Development Economics, 83(2), 302-325.

Platteau, J.-P. (2004). Monitoring elite capture in community-driven development. Development and Change, 35, 223-246.

Platteau, J.-P. (2008). Managing the commons: The role of social norms and beliefs. In P. Bardhan \& I. Ray (Eds.), The contested commons: Conversations between economists and anthropologists. New Delhi: Oxford University Press.

Reid, R. S., Nkedianye, D., Said, M. Y., Kaelo, D., Neselle, M., Makui, O., ... Clark, W. C. (2016). Evolution of models to support community and policy action with science: Balancing pastoral livelihoods and wildlife conservation in savannas of East Africa. Proceedings of the National Academy of Sciences, 113(17), 4579-4584.

Rudel, T. K., Schneider, L., Uriarte, M., Turner, B. L., De Fries, R., Lawrence, D., ... Grau, R. (2009). Agricultural intensification and changes in cultivated areas, 19702005. Proceedings of the National Academy of Sciences of the United States of America (PNAS), 106(49), 20675-20680.

Sanjayan, M. A., Shen, S., \& Jansen, M. (1997). Experiences with integratedconservation development projects in Asia. The World Bank.

Schulz, C. E., \& Skonhoft, A. (1996). Wildlife management, land-use and conflicts. Environment and Development Economics, 1(3), 265-280.

Shively, G., \& Martinez, E. (2001). Deforestation, irrigation, employment, and cautious optimism. In A. Angelsen \& D. Kaimowitz (Eds.), Agricultural technologies and tropical deforestation (pp. 335-346). Wallingford, UK: CABI International.

Skonhoft, A. (1998a). Resource utilization, property rights and welfare-Wildlife and the local people. Ecological Economics, 26, 67-80.
Skonhoft, A. (2007). Economic modeling approaches for wildlife and species conservation. Ecological Economics, 62, 223-231.

Skonhoft, A. (1998b). Resource utilization, property rights and welfare-Wildlife and the local people. Ecological economics, 26(1), 67-80.

Skonhoft, A., \& Solstad, J. T. (1998). The political economy of wildlife exploitation. Land Economics, 16-31.

Smith, M. D. (2002). Two econometric approaches for predicting the spatia behavior of renewable resource harvesters. Land Economics, 78(4), 522-538.

Smith, M. D., Lynhamb, J., Sanchirico, J. N., \& Wilson, J. A. (2010). Political economy of marine reserves: Understanding the role of opportunity costs. Proceedings of the National Academy of Sciences of The United States of America (PNAS), 107(43) $1-6$.

Songorwa, A. N. (1999). Community-based wildlife management (CWM) in Tanzania: Are the communities interested? World Development, 27(12) 2061-2079.

Tachibana, T., \& Nguyen, T. M. (2001). Agricultural intensification versus extensification: A case study of deforestation in the Northern-Hill region of Vietnam. Journal of Environmental Economics and Management, 41, 44-69.

Tarui, N. (2007). Inequality and outside options in common-property resource use Journal of Development Economics, 83(1), 214-239.

Tisdell, C. (2007). Behaviours of conservation organizations and their environmental implications: Analysis based on New (and not so new) Institutional Economics ICAR Discussion Papers 19. Berlin: Humboldt-Universität.

Tullock, G. (1980). Efficient rent-seeking. In J. Buchanan, R. Tollison, \& G. Tullock (Eds.), Towards a theory of the rent-seeking society. College Station: Texas A\&M Press.

Twyman, C. (2017). Community-based natural resource management. The International Encyclopedia of Geography.

Vallino, E. (2009). Community based management of a protected area: The case of GEPRENAF in Burkina Faso. International Journal of Social Forestry, 2(1), 24-42.

Vallino, E. (2013). The tragedy of the park: an agent-based model of endogenous and exogenous institutions for forest management. Ecology and Society, 19(1) 35 [online] URL: http://www.ecologyandsociety.org/vol19/iss1/art35/.

Van Laerhoven, F., \& Ostrom, E. (2007). Traditions and trends in the study of the commons. International Journal of the Commons, 1(1), 3-28.

Vermeulen, C. (2004). Les enjeux de la gestion communautaire de la grande faune: entre tensions foncières et production cotonnière. Le cas de Lara, périphérie du Parc du W, Burkina Faso. Parcs et Réserves, 59(4), 20-27.

Waggoner, P., \& Ausubel, J. (2001). How much will feeding more and wealthier people encroach on forests? Population and Development Review, 27(2), 239-257.

Walker, R. (1993). Deforestation and economic development. Canadian Journal of Regional Science, 16, 481-497.

Wells, M., Brandon, K., \& Hannah, L. (1992). People and parks: Linking protected ared management with local communities. Washington, DC: World Bank, World Wildlife Fund and U.S. Agency for International Development.

Wells, M. P., McShane, T. O., Dublin, H. T., O'Connor, S., \& Redford, K. H. (2004). The future of integrated conservation projects: Building on what works. In T. O. McShane \& M. P. Wells (Eds.), Getting biodiversity projects to work: Towards better conservation and development (pp. 397-422). New York: Columbia University Press.

Wells, M., \& Bradon, K. (1992). People and parks: Linking protected area management with local communities. Washington, DC: World Bank.

Werker, E., \& Ahmed, F. Z. (2008). What do nongovernmental organizations do? Journal of Economic Perspectives, 22(2), 73-92.

Winkler, R. (2011). Why do ICDPs fail? The relationship between agriculture hunting and ecotourism in wildlife conservation. Resource and Energy Economics, 33, 55-78.

Wunder, S. (2001). Poverty alleviation and tropical forests. What scope for synergies? World Development, 29(11), 1817-1833.

Zougouri, S. (2006). Splitted wood as natural resources use: What reality for the management in common of the forest management scheme of Bougnounou (Province of Ziro - Burkina Faso)? 11th Biennal international conference of the international association of the study of the commons, Bali, Indonesia, 17-23 June 2006. 